\title{
PLPP1 Gene
}

National Cancer Institute

\section{Source}

National Cancer Institute. PLPP1 Gene. NCI Thesaurus. Code C24688.

This gene is involved in lipid metabolism/transport and receptor-activated signal transduction. 